\title{
Regulation of NKG2D-Dependent NK Cell Functions: The Yin and the Yang of Receptor Endocytosis
}

\author{
Rosa Molfetta ${ }^{1}$, Linda Quatrini ${ }^{1,2}$, Angela Santoni ${ }^{1}$ and Rossella Paolini ${ }^{1, *}$ \\ 1 Department of Molecular Medicine, Sapienza University of Rome, Laboratory Affiliated to Istituto Pasteur \\ Italia-Fondazione Cenci Bolognetti, Viale Regina Elena 291, 00161 Rome, Italy; \\ rosa.molfetta@uniroma1.it (R.M.); quatrini@ciml.univ-mrs.fr (L.Q.); angela.santoni@uniroma1.it (A.S.) \\ 2 Centre d'Immunologie de Marseille-Luminy, Aix Marseille Université UM2, Inserm, U1104, \\ CNRS UMR7280, 13288 Marseille, France \\ * Correspondence: rossella.paolini@uniroma1.it; Tel.: +39-06-49255670; Fax: +39-06-44340632
}

Received: 12 July 2017; Accepted: 30 July 2017; Published: 2 August 2017

\begin{abstract}
Natural-killer receptor group 2, member D (NKG2D) is a well characterized natural killer (NK) cell activating receptor that recognizes several ligands poorly expressed on healthy cells but up-regulated upon stressing stimuli in the context of cancer or viral infection. Although NKG2D ligands represent danger signals that render target cells more susceptible to NK cell lysis, accumulating evidence demonstrates that persistent exposure to ligand-expressing cells causes the decrease of NKG2D surface expression leading to a functional impairment of NKG2D-dependent NK cell functions. Upon ligand binding, NKG2D is internalized from the plasma membrane and sorted to lysosomes for degradation. However, receptor endocytosis is not only a mechanism of receptor clearance from the cell surface, but is also required for the proper activation of signalling events leading to the functional program of NK cells. This review is aimed at providing a summary of current literature relevant to the molecular mechanisms leading to NKG2D down-modulation with particular emphasis given to the role of NKG2D endocytosis in both receptor degradation and signal propagation. Examples of chronic ligand-induced down-regulation of NK cell activating receptors other than NKG2D, including natural cytotoxicity receptors (NCRs), DNAX accessory molecule-1 (DNAM1) and CD16, will be also discussed.
\end{abstract}

Keywords: innate immune system; natural killer (NK) cells; NK cell receptors

\section{NKG2D/NKG2D Ligand Axis in the Recognition of Damaged Cells}

Activation of natural killer (NK) cells is dictated by a balance between negative signals provided by inhibitory receptors upon interaction with major histocompatibility complex (MHC) class I molecules and positive signals promoted by a variety of activating receptors [1]. Besides the low affinity receptor for IgG (Fc $\gamma$ RIIIA or CD16), that is responsible for the antibody-dependent cell cytotoxicity (ADCC), NK cells express a wide array of activating receptors that cooperate in driving the natural cytotoxic response. These receptors include the natural cytotoxicity receptors (NCRs), the signaling lymphocyte activation molecule (SLAM) family receptor member, 2B4, the Ig-like receptor DNAX accessory molecule-1 (DNAM1), and the lectin-like receptor natural-killer receptor group 2, member D (NKG2D).

NKG2D is a potent activating receptor constitutively expressed on all NK cells but is also present on invariant natural killer T (NKT) cells and subsets of T cells including CD $8^{+} \alpha \beta \mathrm{T}$ cells, and $\gamma \delta \mathrm{T}$ cells. It can bind several ligands poorly expressed on healthy cells, but is up-regulated upon stressing stimuli in the context of cancer or viral infection [2-5]. Several in vivo models support a fundamental role for the NKG2D receptor in NK cell responses toward abnormal cells. Ectopic expression of NKG2D ligands (NKG2DLs) causes tumor rejection in syngeneic mouse models despite MHC class I expression [6,7], while NKG2D deficiency impairs surveillance towards spontaneous malignancies [8,9]. 
NKG2D functions as co-stimulatory rather than a stimulatory receptor: on human $\mathrm{CD}^{+} \mathrm{T}$ cells it potentiates $\mathrm{T}$ cell receptor (TCR)-induced cytotoxic function [10], while on freshly isolated human NK cells its engagement alone is not sufficient to promote full NK cell functional responses [11]. In particular, the synergistic co-engagement of 2B4 receptor is required to overcome negative signals mediated by inhibitory receptors [12,13]. To propagate signals, human NKG2D needs to associate with the transmembrane adaptor DNAX activating protein 10 (DAP10) [14], which contains a tyrosine-based motif (YINM). Ligand binding promotes the phosphorylation of YINM domain allowing the recruitment of the growth factor receptor-bound protein 2 (Grb2)/Vav1 complex and the activation of phosphatidyl-inositol-3-kinase (PI3K) [14,15]. PI3K promotes survival pathways through the activation of Akt, while the recruitment of Grb2/Vav1 complex allows phosphorylation of Vav1 and the consequent activation of Phospholipase C gamma (PLC $\gamma 2$ ), and of the Src homology 2 (SH2) domain-containing leukocyte protein of $76 \mathrm{kD}$ (SLP-76) [16].

Upon activation, murine NK cells express an alternatively spliced isoform (NKG2D-S) that can associate with DAP10 or DAP12 adaptor proteins. The presence of an immune tyrosine-based activation motif (ITAM) in DAP12 cytoplasmic region allows the recruitment of Syk and ZAP70 tyrosine kinases and the consequent PLC $\gamma$ phosphorylation and PI3K activation $[17,18]$.

The most remarkable characteristic of NKG2D receptor resides in its ability to bind to a large repertoire of self-proteins induced by stress pathways, thus mediating the "induced self" recognition [2-5]. In humans, these ligands include the highly polymorphic MHC class I related proteins (MIC)A and MICB, and 6 members of UL16 binding proteins (ULBP). In mice only genes orthologous to the human $U L P B / R A E T 1$ family are present, and encode three subgroups of proteins: the GPI-linked RAE-1 (retinoic acid early inducible-1), MULT1 (murine UL16-binding protein-like transcript 1) and $\mathrm{H} 60$ ligands [3,4].

NKG2DLs are absent on the surface of the vast majority of healthy tissues but are up-regulated under stressing conditions, including mitosis, viral infection and cancer by several pathways mainly acting at transcriptional and post-transcriptional levels $[3,19,20]$.

The activation of the DNA Damage Response (DDR) is recognized as the major signalling pathway responsible for the transcriptional up-regulation of NKG2DL expression [3,19-22]. This pathway, initiated by ataxia telangiectasia mutated (ATM), ATM and Rad3-related (ATR) and the DNA-dependent protein kinase (DNA-PK), promotes NKG2DL expression on healthy proliferating cells $[23,24]$. Moreover, DDR-mediated pathway may be activated upon infection by several viruses, including herpes viruses, adenoviruses and retroviruses, and is responsible for NKG2DL up-regulation. However, while a direct link between these two phenomena has been established for HIV-1 [25,26], up-regulation of MICA upon human cytomegalovirus (HCMV) infection appears to be independent from DDR induction and is directly promoted by viral proteins [27]. In cancer cells, genotoxic stress increases the sensitivity of tumor cells to NK cell-mediated lysis by the induction of NKG2DL expression mainly through DDR activation [19-21]. Moreover, this pathway is up-regulated by genotoxic chemotherapeutic drugs that enhance NKG2DL expression preferentially in cells undergoing senescence, thus supporting the notion that drug-induced senescence represents a mechanism that contribute to the NK cell-mediated tumor cell clearance [20-22].

In addition, the heat shock pathway, the oxidative stress pathway and the endoplasmic reticulum stress response may act together with the DDR pathway to ensure NKG2DL expression in unhealthy cells $[3,4]$. Anti-cancer therapeutic interventions may also improve the efficacy of NK cell immune-surveillance affecting NKG2DL expression in tumor cells, as demonstrated by several evidences including those obtained on the hematological cancer Multiple Myeloma (MM) [28-32].

Although stressing conditions ensure NKG2DL expression on transformed and infected cells, both viruses (e.g., HCMV, HIV-1) and cancer cells have developed the capability to inhibit cell-surface NKG2DL expression in order to counteract NKG2D-mediated recognition. Some viruses encoded proteins, such as UL16 and UL142 of HCMV [33-35] or HIV-Nef [36] can cause NKG2DL intracellular retention. During tumor progression, immunoediting processes favor the selection of 
tumor variants that dampen NKG2DL membrane expression producing soluble ligands through alternative splicing [37,38], proteolytic shedding mediated by metalloproteinases of A Disintegrin And Metalloproteinase (ADAM) family [39-42] or exosome secretion [43,44].

\section{Ligand-Dependent NKG2D Down-Modulation: Impact on NK Cell Function}

Although expression of NKG2DLs represents a danger signal sufficient to alert NK cells against damaged cells, in condition of chronic exposure to NKG2DL-expressing cells or soluble NKG2DLs, receptor down-modulation occurs with the consequent impairment of NKG2D-mediated cytotoxic cell functions [39,45-52].

The first evidence of NKG2D down-regulation comes from studies of Groh and co-workers on $\mathrm{CD} 8^{+}$tumor infiltrating $\mathrm{T}$ lymphocytes: NKG2D down-modulation was induced either upon chronic stimulation with target cells expressing the ligand MIC or with patients' sera containing soluble MICA/B [45]. These findings were followed by in vitro and in vivo evidences demonstrating that engagement with both MIC and ULBP ligands induces NKG2D down-modulation on human NK cells [39,46,49-51]. The presence of MIC ligands in sera derived from patients with colorectal cancer correlated with a reduction of NKG2D expression on circulating NK cells that resulted unable to kill $\mathrm{MIC}^{+}$autologous tumor cells [46]. NKG2D down-modulation was also observed on NK cells incubated with ULBP-transfected cells or primary $\mathrm{ULBP2}^{+}$leukemic cells [39]. However, in this experimental setting NKG2D expression was not affected by soluble form of ULBP2 released in the culture supernatants by metalloproteinase-mediated shedding.

In order to analyse whether different membrane-bound NKG2DLs are equally able to induce NKG2D down-modulation, transfectants expressing MICA or ULBP2 have been co-cultured with human primary NK cells [51]. MICA and ULBP2 vary in their potential to induce NKG2D down-modulation, with MICA being the most potent ligand leading to a severe impairment of NKG2D-dependent NK cell cytotoxicity. These results suggest that the intrinsic ability of distinct ligands to reduce NKG2D expression may be due to differences in their affinity / avidity for NKG2D and / or to their mode of membrane anchor (transmembrane and GPI-linked, respectively).

With regard to the ability of human soluble ligands to down-regulate their receptor and impair NKG2D-mediated cytolytic functions, contrasting results exist. Down-modulation of NKG2D expression on $\mathrm{CD}^{+} \mathrm{T}$ cells was observed in patients with different epithelial cancers and correlated with the presence of soluble MICA/B in their sera [45]. NKG2D expression was also found reduced on circulating NK cells from patients with colorectal cancer that display the presence of soluble MIC ligand in sera [46]. In contrast, in MM patients only membrane-bound NKG2DLs induce NKG2D down-modulation, despite the presence of soluble ligands in patients' sera [53]. Similarly, high concentrations of soluble MICA in sera of patients affected by autoimmune diseases are not associated with any changes in NKG2D surface expression [54-56]. In line with these data, NKG2DLs released into culture supernatants not always leads to receptor down-modulation [39,57,58]. NKG2D surface expression does not change upon stimulation with metalloproteinase-shed ULBP2 [39], while it was found reduced upon incubation with high concentrations of recombinant soluble ULPB2 [57]. On the other hand, MICB released in vitro from activated $\mathrm{CD}^{+}$lymphocyte down-regulate NKG2D expression on $\mathrm{CD} 8^{+} \mathrm{T}$ cells [58].

These conflicting results may be explained by the different nature of the soluble ligands (shed by proteolytic cleavage or released in exosomes). Comparing the results obtained with shed and exosome-release ligands it appears that these latter forms are more potent down-modulators than the shed counterparts. Indeed, culture supernatants containing exosome-released MICA*008 are more potent down-modulators than metalloproteinase-shed MICA [43]. Moreover, exosome-released ULBP3 decreases receptor expression more efficiently than the metalloproteinase-shed ULBP2 ligand [44]. Similar results were obtained upon chronic exposure to tumor derived MIC-expressing exosomes: they induce down-modulation of NKG2D surface expression on NK and CD8 ${ }^{+} \mathrm{T}$ lymphocytes, thus reducing their ability to produce IFN- $\gamma$ and to kill tumor cells [50]. Moreover, during pregnancy 
exosomes bearing NKG2DLs are secreted by syncytiotrophoblast and contribute to immune tolerance of the fetus by reducing NKG2D surface expression and function on maternal circulating PBMCs [59]. These results may be explained considering that the surface of exosomes exposes multiple ligand molecules that engage NKG2D with high avidity.

Several lines of evidence obtained on mouse models also support a role for both human and mouse membrane-bound ligands in NKG2D down-modulation and functional impairment (Table 1). NKG2D down-modulation on activated NK cells in nonobese diabetic (NOD) mice is responsible for a reduced cytotoxicity and cytokine production [47]. In transgenic mice overexpressing MICA, NK and $\mathrm{CD}^{+} \mathrm{T}$ cells were unable to reject MICA-positive tumors due to a reduced receptor expression [49]. In addition, two transgenic models of the mouse ligand Rae- 1 expression have also been used to demonstrate that NKG2D down-modulation leads to NK cell functional impairment [48,60].

Table 1. In vivo models demonstrating that chronic exposure to NKG2DLs results in receptor down-regulation.

\begin{tabular}{|c|c|c|}
\hline Experimental Mouse Model & Findings & Reference \\
\hline Nonobese diabetic (NOD) mice & $\begin{array}{ll}\text { - } & \text { NKG2D down-modulation on activate NK cells } \\
\text { - } & \text { Impaired NKG2D-dependent NK cell functions }\end{array}$ & [47] \\
\hline $\begin{array}{l}\text { FVB transgenic mice } \\
\text { overexpressing Rae-1 } 1 \varepsilon \text { ligand } \\
\text { ubiquitously or localized in } \\
\text { normal epithelium }\end{array}$ & $\begin{array}{ll}\text { - } & \text { NKG2D down-modulation on splenic NK cells (and } \\
\text { intraepithelial T cells) } \\
\text { - } \\
\text { - } \quad \text { Normaired NKG2D-dependent NK cell functions } \\
\text { - } \quad \text { Increased susceptibility to tumorigenesis }\end{array}$ & [48] \\
\hline $\begin{array}{l}\text { C57BL/ } 6 \text { transgenic mice } \\
\text { constitutively and ubiquitously } \\
\text { overexpressing MICA }\end{array}$ & $\begin{array}{ll}\text { - } & \text { NKG2D down-modulation on splenic NK cells } \\
\text { - } & \text { Impaired NKG2D-dependent functions in vivo and in vitro } \\
\text { - } & \text { Impaired CD8 T cell response to L. monocytogeneses }\end{array}$ & [49] \\
\hline $\begin{array}{l}\text { C57BL/ } 6 \text { transgenic mice } \\
\text { ubiquitously overexpressing } \\
\text { Rae- } 1 \varepsilon \text { ligand }\end{array}$ & $\begin{array}{ll}\text { - } & \text { NKG2D down-modulation on splenic NK cells } \\
\text { - } & \text { Impaired NKG2D-dependent NK cell functions } \\
\text { - } & \text { Normal NK and CD8 T cell response to MCMV }\end{array}$ & [60] \\
\hline
\end{tabular}

NKG2D, natural-killer receptor group 2, member D; NK, natural killer; CTL, cytotoxic T lymphocytes; MCMV, murine cytomegalovirus.

In in vitro experiments, $\mathrm{H} 60$ membrane-bound ligand resulted in down-regulation of NKG2D expression and its associated functions in murine NK cells [61]. Regarding the soluble forms of murine NKG2DLs, it is interesting to point out that soluble MULT1 promotes tumor rejection by blocking the interaction with NKG2DLs expressed on non-tumor host cell, thus preventing continuous NKG2D down-modulation and NK cell desensitization [62]. These results strongly argued against a role of soluble monomeric murine NKG2DLs in immune evasion.

All together these evidences support the conclusion that a persistent engagement with membrane-bound or exosomal NKG2DLs down-modulates NKG2D on cytotoxic lymphocytes and ultimately, affects their killing capability towards NKG2DL-bearing target cells.

A still open question is whether NKG2D down-regulation impacts on other unrelated NK cell-activating receptor-dependent functions. Upon an overnight co-culture with MICA- and ULBP2-expressing target cells, human NK cells reduce NKG2D expression and function, while maintain intact cytotoxic function triggered by other activating receptors [51]. However, longer in vitro stimulation with NKG2DLs has been shown to impact on NKG2D unrelated functions both in human and mice. In fact, $\mathrm{CD} 3 \zeta$ chain degradation was observed in human $\mathrm{CD} 8^{+} \mathrm{T}$ lymphocytes and NK cells upon 3 days of co-culture with MICA-transfectants [63], and in murine NK cells stimulated for 3 days with H60-expressing targets [64], thus impairing the functional capacity of $\mathrm{CD} 3 \zeta$-associated receptors.

Notably, NKG2D expression may also be regulated by ligand-independent signals. Indeed, it was extensively reported that TGF- $\beta$ down-regulates human NKG2D surface expression interfering with DAP10 transcription [65-67]. Moreover, several cytokines including IL-2, IL-7, IL-12, and IL-15, increase NKG2D/DAP10 expression acting at transcriptional and post-transcriptional level $[5,66]$. 
Altogether these results suggest that the functional consequences of NKG2D down-modulation may depend not only on the nature of the ligand and the lengths of receptor stimulation but also on the concurrent action of cytokines.

\section{NKG2D Endocytosis: Intracellular Receptor Trafficking and Signalling}

Regarding the mechanisms of NKG2D down-modulation, several lines of evidence support a pivotal role for ligand-induced receptor endocytosis. Upon ligand binding, both murine and human NKG2D receptors are mainly internalized by clathrin-dependent endocytosis [47,58], and rapidly traffics through endosomal compartment towards lysosomes where both NKG2D and DAP10 are degraded [45,51,68]. However, receptor engagement with MICA is more rapidly followed by lysosomal degradation if compared to ULBP2 [51], suggesting that the rate of receptor internalization and degradation depends on the nature of the ligand. These differential effects may be explained by a selective activation of the ubiquitin pathway that promotes a more rapid receptor endocytosis. Indeed, the ubiquitin ligase c-Cbl is required for MICA- but not ULBP2-induced NKG2D endocytosis [51]. Notably, in human NK cells NKG2D internalization and degradation depend on DAP10 ubiquitination [69]. In line with these results, in a murine model NKG2D/DAP10 degradation was observed when DAP10 was fused with a molecule of ubiquitin [70], suggesting that this pathway can be also implicated in murine NKG2D endocytosis.

Regarding the fate of murine internalized receptors, conflicting results exist. The expression level of both NKG2D associated DAP10 and DAP12 was reduced after stimulation of murine NK cells with transfectants over-expressing the NKG2DL H60 [61], whereas NKG2D internalization was not followed by receptor degradation upon interaction of murine NK cells with Rae1 $\varepsilon$-bearing targets [47]. These findings suggest that also in mouse the kind of NKG2DLs and/or the length of NKG2D/NKG2DL stimulation differently impacts on the fate of internalized receptor complexes.

Even though persistent stimulation with cognate ligands promotes receptor down-modulation and dampens NK cell functions, recent evidences demonstrated that ubiquitin-dependent NKG2D endocytosis is indispensable for the propagation of intracellular signals leading to human NK cell function $[52,69]$. Indeed, although proximal events occur at the plasma membrane, the full activation of Extracellular signal-Regulated Kinases 1 and 2 (ERK1/2) requires receptor internalization and sorting in endosomal compartments [69]. NK cells in which NKG2D internalization is inhibited resulted in impairment of both their cytotoxic function and cytokine production [69]. These results demonstrate that NKG2D continues to signal upon internalization, but also support the notion that endocytosis elicits a fundamental role in the regulation of the NKG2D-dependent functional program.

Altogether these data support a model in which the internalized NKG2D/DAP10 complexes contribute to the recruitment of ERK, which is a critical signal element in driving NK cell cytotoxicity [71], to endosomal compartments where ERK is phosphorylated and activated, thus allowing signal propagation and functional responses. On the other hand, persistent stimulation and receptor endocytosis leads to lysosomal degradation of activated receptor complexes and dampens NKG2D-mediated functions (Figure 1). Whether murine NKG2D that mediates ITAM-dependent signals may also require receptor endocytosis is currently unknown.

Endosomes can function as platforms to initiate and/or to sustain receptor-mediated signals, as supported by several findings that document a close relationship between endocytosis and signalling.

In the context of ligand-induced down-regulation of receptor tyrosine kinases (RTKs) as well as G protein-coupled receptors (GPCR) [72,73], the rate of ligand-induced receptor internalization is very high with respect to the rate of receptor degradation, and this long receptor residence in endosomes serves to sustain the signalling.

Several evidences support the concept that endosomes can act to initiate and/or to sustain receptor-mediated signal also in immune cells. The Toll-like Receptors (TLR) TLR3, TLR7, and TLR9 initiate signalling upon their ligand-induced internalization [74], whereas TLR4 activates different signalling pathways depending on its cellular location, regulating the production of diverse 
inflammatory cytokines [75]. The role of endosomes has also been demonstrated for B and T cell receptors-mediated signalling. In those cases, internalized receptors ensure the appropriate extent and strength of signalling, respectively [76,77]. Regarding NK cells, the activating receptor KIR2DL4 accumulates into early endosomes in order to initiate a pro-inflammatory cascade $[78,79]$. With respect to the NKG2D-DAP10 complex on human NK cells, the finding that internalized receptors are rapidly degraded [69], suggests that endosomal signalling is required to amplify MAPK/ERK signal but not to sustain it.

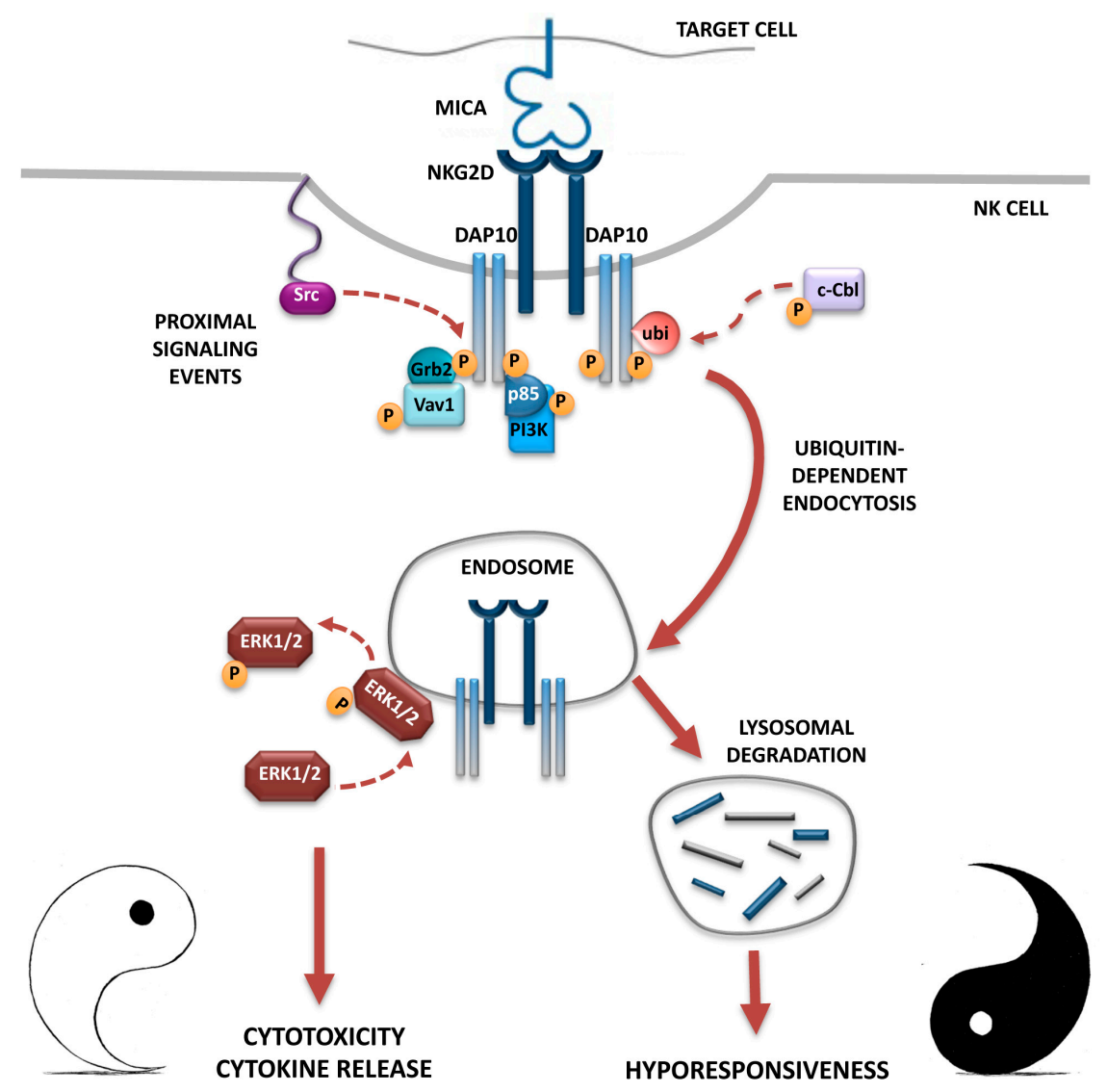

Figure 1. The Yin and Yang of NKG2D endocytosis: functional consequences on NKG2D-mediated signaling and NK cell effector functions. In human NK cells, NKG2D engagement by MICA induces Vav1 phosphorylation and PI3K activation, which are responsible for the initiation of intracellular signals leading to effector functions. On the other hand, MICA engagement activates the ubiquitin ligase c-Cbl and promotes DAP10 ubiquitination that provides a signal responsible for NKG2D internalization and lysosomal degradation, that ultimately induces a hyporesponsiveness towards NKG2DL-bearing target cells (the black part of the Yin-Yang symbol). However, internalized NKG2D receptors before being degraded continue to signal from endosomes: they promote ERK1/2 phosphorylation allowing the full activation of NK cells (the white part of the Yin-Yang symbol). NKG2D/DAP10 receptor complexes are depicted with intact rectangles (cell surface membrane and endosomes), and with fragmented rectangles (lysosomes) to indicate that their degradation was occurred. Arrows represent relationships that were well established (solid lines) or not yet demonstrated (dashed lines). Modified from Quatrini et al. [69].

In conclusion, these results provide new insight on the role of the endosome in NKG2D-mediated signal propagation and regulation of NK cell functions that could be extended to other NK cell activating receptors. 


\section{Down-Modulation of Other Activating NK Cell Receptors and Their Impact of NK Cell Function}

Besides NKG2D, NCRs, DNAM1 and CD16 are the best-characterized activating NK cell receptors implicated in immune responses against cancer [1]. Interestingly, numerous evidences have revealed alterations of the surface expression of those NK cell receptors upon sustained engagement with their respective ligands in tumor-patients [80-88].

NCRs comprise NKp44, NKp30, and NKp46 [89], and all of them have been implicated in anti-tumor immune responses on the basis of the ability of monoclonal antibodies (mAbs) against these receptors to block human NK cell killing of various tumor cell lines [90]. In many cases, combining the Abs against NKp30, NKp44 and NKp46 resulted in more efficient blocking of NK-mediated tumor cell lysis than the same Abs used individually, suggesting the existence of multiple ligands on the target cells. However, the full identification of NCR ligands remains to be performed. The only cell surface ligand known to bind to an NCR is the NKp30 ligand B7-H6, a member of the B7 family exclusively expressed on tumor cells [91]. The importance of this receptor family in the context of NK cell-mediated tumor immune-surveillance raises the possibility that cancer cells can shape NCR expression in order to prevent NK cell recognition. Indeed, upon direct contact with leukemic cells a reduced NKp30 and NKp46 expression was observed on NK cells derived from acute myeloid leukemia (AML) patients [80]. In line with these results, reduced NKp30 level was observed on NK cells derived from peritoneal fluid of ovarian carcinoma patients compared to autologous peripheral blood NK cells [85]. NKp30 down-modulation is a consequence of chronic stimulation with both tumor cell expressing the NKp30 ligand B7-H6 and soluble B7-H6 present in peritoneal fluid. Consequently, NK cells showing an NKp30 ${ }^{\text {low }}$ phenotype resulted impaired in both cytotoxic function and IFN $\gamma$ production when stimulated with B7-H6 bearing target cells [85]. Similarly, high levels of soluble B7-H6 ligand in the sera of neuroblastoma patients correlates with NKp30 down-modulation on circulating NK cells and impaired NKp30-dependent NK cell activation and disease progression [86]. All together these results suggest that, in the case of B7-H6 ligand, both membrane-bound and soluble molecule are equally able to reduce surface receptor expression.

DNAM1 receptor binds to the poliovirus receptor CD155 and the Nectin adhesion molecule CD112, both up-regulated in stressed cells, and has a pivotal role in preventing spontaneous tumor formation and in controlling tumor growth [92]. However, evidence exist that chronic stimulation with DNAM1 ligands in the context of tumor transformation provokes receptor down-modulation on NK cells [81-83]. Significant DNAM1 down-modulation was observed on NK cells derived from MM patients compared to healthy donors [81], although a role of MM-expressed DNAM1 ligands has not been directly assessed. In line with these results, NK cells from peritoneal fluids of ovarian carcinoma patients show reduced DNAM1 surface expression levels as a consequence of persistent stimulation with CD155 expressed on cancer cells [82]. Notably, DNAM1 down-modulation required cell-cell contacts, thus excluding the contribution of soluble CD155 present in peritoneal fluid [82]. Moreover, in NK cells from AML patients, down-modulation of DNAM1 receptor is induced by a direct contact with leukemic blasts expressing both CD155 and CD112 DNAM1 ligands, and leads to an impaired natural cytotoxicity [83]. Altogether these results support a role for cell membrane DNAM1 ligands, but not for their soluble counterpart, in promoting receptor down-regulation.

The molecular mechanisms responsible for DNAM1 and NCR down-modulation have not been clarified yet. In particular, it would be interesting to investigate the involvement of either endocytosis or metalloproteinase-mediated shedding and intracellular transfer during effector-target interaction (trogocytosis).

CD16 (Fc $\gamma$ RIIIA) is a potent activating receptor expressed on the $\mathrm{CD} 56^{\mathrm{dim}} \mathrm{CD} 16^{+} \mathrm{NK}$ cell subset that mediates ADCC and cytokine release [93] through the tyrosine phosphorylation of its transducing subunits [94,95]. In particular, ADCC activity has been associated with better outcomes for some type of cancers [96]. Many therapeutic monoclonal antibodies $(\mathrm{mAb})$ that specifically recognize tumor cells are able to bind to CD16 on NK cells, promoting NK cell-mediated ADCC of these tumor cells $[97,98]$. 
In response to $\mathrm{mAb}$-coated tumor cells, however, $\mathrm{CD} 16$ is down-modulated from the cell surface of NK cells, leading to impaired NK cell function and decreasing the efficacy of Ab-based therapies $[84,87,88]$. Thus, identification of the molecular mechanism(s) responsible for CD16 down-regulation has clinical significance. Several findings have reported that Ab-mediated CD16 down-modulation is mainly a consequence of metalloproteinases (MMPs)-induced shedding [99-102]. Indeed, treatment with MMPs inhibitors preserved CD16 expression and restored impaired NK cell-mediated ADCC [84]. Notably, CD16 down-regulation also depends on internalization of cross-linked receptors as reported upon anti-CD16 mAb engagement $[103,104]$ or upon co-culture with tumor target cells opsonized with therapeutic Abs [84,87,88]. Receptor endocytosis requires an integral and functional cytoskeleton [104], a clathrin-dependent pathway (Molfetta, preliminary results), and is followed by ubiquitin-dependent degradation of CD16-associated signaling elements $[88,105,106]$. Intriguingly, as a result of this NK cells are not only impaired in their ability to further perform ADCC, but also to induce spontaneous cytotoxic activity triggered by unrelated activating receptors including NKG2D, DNAM1 and NCRs, while they maintain the ability to produce IFN $\gamma$ [88]. It would be interesting to investigate in the future whether CD16 endocytosis is required to activate the functional program of NK cells, as formally demonstrated in the case of NKG2D.

\section{Concluding Remarks}

NKG2D is one of the main NK cell activating receptor involved in anti-tumor and anti-viral immune response. However, persistent exposure to NKG2D ligand-expressing target cells promotes NKG2D down-modulation that leads to lysosomal receptor degradation with the consequent impairment of NKG2D-mediated functions. Intriguingly, receptor complexes before being degraded promote ERK1/2 phosphorylation from endosomes and ensure NK cell full activation.

Ligand-induced down-modulation from the cell membrane has been demonstrated also for NK cell activating receptors other than NKG2D. It would be interesting to investigate whether these receptors are down-modulated by endocytosis, and whether they can signal from endosomal compartments. Considering that NK cell activation requires the co-engagement of at least two activating receptors, endosomal membranes would provide a platform for the integration of these signals, thus ensuring a better control of NK cell response.

Acknowledgments: We apologize to all our colleagues whose important work could not be cited directly. Most of these references can be found in the review articles cited in the manuscript. Work in our laboratory is supported by grants from the Italian Association for Cancer Research (AIRC), the Italian Ministry for University and Research (MIUR-FIRB; PRIN/20103FMJEN/AngelaSantoni), and the Center of Excellence (BEMM).

Conflicts of Interest: The authors declare no conflict of interest.

\section{References}

1. Long, E.O.; Kim, H.S.; Liu, D.; Peterson, M.E.; Rajagopalan, S. Controlling natural killer cell responses: Integration of signals for activation and inhibition. Annu. Rev. Immunol. 2013, 31, 227-258. [CrossRef] [PubMed]

2. Eagle, R.A.; Trowsdale, J. Promiscuity and the single receptor: NKG2D. Nat. Rev. Immunol. 2007, 7, 737-744. [CrossRef] [PubMed]

3. Raulet, D.H.; Gasser, S.; Gowen, B.G.; Deng, W.; Jung, H. Regulation of ligands for the NKG2D activating receptor. Annu. Rev. Immunol. 2013, 31, 413-441. [CrossRef] [PubMed]

4. Ullrich, E.; Koch, J.; Cerwenka, A.; Steinle, A. New prospects on the NKG2D/NKG2DL system for oncology. Oncoimmunology 2013, 2, e26097. [CrossRef] [PubMed]

5. Lanier, L.L. NKG2D Receptor and Its Ligands in Host Defense. Cancer Immunol. Res. 2015, 3, 575-582. [CrossRef] [PubMed]

6. Cerwenka, A.; Baron, J.L.; Lanier, L.L. Ectopic expression of retinoic acid early inducible-1 gene (RAE-1) permits natural killer cell-mediated rejection of a MHC class I-bearing tumor in vivo. Proc. Natl. Acad. Sci. USA 2001, 98, 11521-11526. [CrossRef] [PubMed] 
7. Diefenbach, A.; Jensen, E.R.; Jamieson, A.M.; Raulet, D.H. Rae1 and H60 ligands of the NKG2D receptor stimulate tumour immunity. Nature 2001, 413, 165-171. [CrossRef] [PubMed]

8. Guerra, N.; Joncker, N.T.; Choy, A.; Gallardo, F.; Xiong, N.; Knoblaugh, S.; Cado, D.; Greenberg, N.M.; Raulet, D.H. NKG2D-deficient mice are defective in tumor surveillance in models of spontaneous malignancy. Immunity 2008, 28, 571-580. [CrossRef] [PubMed]

9. Zafirova, B.; Mandarić, S.; Antulov, R.; Krmpotić, A.; Jonsson, H.; Yokoyama, W.M.; Jonjić, S.; Polić, B. Altered NK cell development and enhanced NK cell-mediated resistance to mouse cytomegalovirus in NKG2D-deficient mice. Immunity 2009, 31, 270-282. [CrossRef] [PubMed]

10. Jelenčić, V.; Lenartić, M.; Wensveen, F.M.; Polić, B. NKG2D: A versatile player in the immune system. Immunol. Lett. 2017. [CrossRef] [PubMed]

11. Bryceson, Y.T.; Ljunggren, H.G.; Long, E.O. Minimal requirement for induction of natural cytotoxicity and intersection of activation signals by inhibitory receptors. Blood 2009, 114, 2657-2666. [CrossRef] [PubMed]

12. Kim, H.S.; Das, A.; Gross, C.C.; Bryceson, Y.T.; Long, E.O. Synergistic signals for natural cytotoxicity are required to overcome inhibition by c-Cbl ubiquitin ligase. Immunity 2010, 32, 175-186. [CrossRef] [PubMed]

13. Kim, H.S.; Long, E.O. Complementary phosphorylation sites in the adaptor protein SLP-76 promote synergistic activation of natural killer cells. Sci. Signal. 2012, 5, ra49. [CrossRef] [PubMed]

14. Bauer, S.; Groh, V.; Wu, J.; Steinle, A.; Phillips, J.H.; Lanier, L.L.; Spies, T. Activation of NK cells and T cells by NKG2D, a receptor for stress-inducible MICA. Science 1999, 285, 727-729. [CrossRef] [PubMed]

15. Wu, J.; Song, Y.; Bakker, A.B.; Bauer, S.; Spies, T.; Lanier, L.L.; Phillips, J.H. An activating immunoreceptor complex formed by NKG2D and DAP10. Science 1999, 285, 730-732. [CrossRef] [PubMed]

16. Upshaw, J.L.; Leibson, P.J. NKG2D-mediated activation of cytotoxic lymphocytes: Unique signaling pathways and distinct functional outcomes. Semin. Immunol. 2006, 18, 167-175. [CrossRef] [PubMed]

17. Diefenbach, A.; Tomasello, E.; Lucas, M.; Jamieson, A.M.; Hsia, J.K.; Vivier, E.; Raulet, D.H. Selective associations with signaling proteins determine stimulatory versus costimulatory activity of NKG2D. Nat. Immunol. 2002, 3, 1142-1149. [CrossRef] [PubMed]

18. Gilfillan, S.; Ho, E.L.; Cella, M.; Yokoyama, W.M.; Colonna, M. NKG2D recruits two distinct adapters to trigger NK cell activation and costimulation. Nat. Immunol. 2002, 3, 1150-1155. [CrossRef] [PubMed]

19. Gasser, S.; Orsulic, S.; Brown, E.J.; Raulet, D.H. The DNA damage pathway regulates innate immune system ligands of the NKG2D receptor. Nature 2005, 436, 1186-1190. [CrossRef] [PubMed]

20. Cerboni, C.; Fionda, C.; Soriani, A.; Zingoni, A.; Doria, M.; Cippitelli, M.; Santoni, A. The DNA Damage Response: A Common Pathway in the Regulation of NKG2D and DNAM-1 Ligand Expression in Normal, Infected, and Cancer Cells. Front. Immunol. 2014, 4, 508. [CrossRef] [PubMed]

21. Soriani, A.; Zingoni, A.; Cerboni, C.; Iannitto, M.L.; Ricciardi, M.R.; di Gialleonardo, V.; Cippitelli, M.; Fionda, C.; Petrucci, M.T.; Guarini, A.; et al. ATM-ATR-dependent up-regulation of DNAM-1 and NKG2D ligands on multiple myeloma cells by therapeutic agents results in enhanced NK-cell susceptibility and is associated with a senescent phenotype. Blood 2009, 113, 3503-3511. [CrossRef] [PubMed]

22. Soriani, A.; Iannitto, M.L.; Ricci, B.; Fionda, C.; Malgarini, G.; Morrone, S.; Peruzzi, G.; Ricciardi, M.R.; Petrucci, M.T.; Cippitelli, M.; et al. Reactive oxygen species- and DNA damage response-dependent NK cell activating ligand upregulation occurs at transcriptional levels and requires the transcriptional factor E2F1. J. Immunol. 2014, 193, 950-960. [CrossRef] [PubMed]

23. Groh, V.; Bahram, S.; Bauer, S.; Herman, A.; Beauchamp, M.; Spies, T. Cell stress-regulated human major histocompatibility complex class I gene expressed in gastrointestinal epithelium. Proc. Natl. Acad. Sci. USA 1996, 93, 12445-12450. [CrossRef] [PubMed]

24. Cerboni, C.; Zingoni, A.; Cippitelli, M.; Piccoli, M.; Frati, L.; Santoni, A. Antigen-activated human T lymphocytes express cell-surface NKG2D ligands via an ATM/ATR-dependent mechanism and become susceptible to autologous NK-cell lysis. Blood 2007, 110, 606-615. [CrossRef] [PubMed]

25. Ward, J.; Davis, Z.; DeHart, J.; Zimmerman, E.; Bosque, A.; Brunetta, E.; Mavilio, D.; Planelles, V.; Barker, E. HIV-1 Vpr triggers natural killer cell-mediated lysis of infected cells through activation of the ATR-mediated DNA damage response. PLoS Pathog. 2009, 5, e1000613. [CrossRef] [PubMed]

26. Richard, J.; Sindhu, S.; Pham, T.N.; Belzile, J.P.; Cohen, E.A. HIV-1 Vpr up-regulates expression of ligands for the activating NKG2D receptor and promotes NK cell-mediated killing. Blood 2010, 115, 1354-1363. [CrossRef] [PubMed] 
27. Pignoloni, B.; Fionda, C.; Dell'Oste, V.; Luganini, A.; Cippitelli, M.; Zingoni, A.; Landolfo, S.; Gribaudo, G.; Santoni, A.; Cerboni, C. Distinct Roles for Human Cytomegalovirus Immediate Early Proteins IE1 and IE2 in the Transcriptional Regulation of MICA and PVR/CD155 Expression. J. Immunol. 2016, 197, 4066-4078. [CrossRef] [PubMed]

28. Jinushi, M.; Vanneman, M.; Munshi, N.C.; Tai, Y.T.; Prabhala, R.H.; Ritz, J.; Neuberg, D.; Anderson, K.C.; Carrasco, D.R.; Dranoff, G. MHC class I chain-related protein A antibodies and shedding are associated with the progression of multiple myeloma. Proc. Natl. Acad. Sci. USA 2008, 105, 1285-1290. [CrossRef] [PubMed]

29. Wu, X.; Tao, Y.; Hou, J.; Meng, X.; Shi, J. Valproic acid upregulates NKG2D ligand expression through an ERK-dependent mechanism and potentially enhances NK cell-mediated lysis of myeloma. Neoplasia 2012, 14, 1178-1189. [CrossRef] [PubMed]

30. Fionda, C.; Abruzzese, M.P.; Zingoni, A.; Cecere, F.; Vulpis, E.; Peruzzi, G.; Soriani, A.; Molfetta, R.; Paolini, R.; Ricciardi, M.R.; et al. The IMiDs targets IKZF-1/3 and IRF4 as novel negative regulators of NK cell-activating ligands expression in multiple myeloma. Oncotarget 2015, 6, 23609-23630. [CrossRef] [PubMed]

31. Abruzzese, M.P.; Bilotta, M.T.; Fionda, C.; Zingoni, A.; Soriani, A.; Vulpis, E.; Borrelli, C.; Zitti, B.; Petrucci, M.T.; Ricciardi, M.R.; et al. Inhibition of bromodomain and extra-terminal (BET) proteins increases NKG2D ligand MICA expression and sensitivity to NK cell-mediated cytotoxicity in multiple myeloma cells: Role of cMYC-IRF4-miR-125b interplay. J. Hematol. Oncol. 2016, 9, 134. [CrossRef] [PubMed]

32. Soriani, A.; Borrelli, C.; Ricci, B.; Molfetta, R.; Zingoni, A.; Fionda, C.; Carnevale, S.; Abruzzese, M.P.; Petrucci, M.T.; Ricciardi, M.R.; et al. p38 MAPK differentially controls NK activating ligands at transcriptional and post-transcriptional level on multiple myeloma cells. Oncoimmunology 2016, 6, e1264564. [CrossRef] [PubMed]

33. Welte, S.A.; Sinzger, C.; Lutz, S.Z.; Singh-Jasuja, H.; Sampaio, K.L.; Eknigk, U.; Rammensee, H.G.; Steinle, A. Selective intracellular retention of virally induced NKG2D ligands by the human cytomegalovirus UL16 glycoprotein. Eur. J. Immunol. 2003, 33, 194-203. [CrossRef] [PubMed]

34. Ashiru, O.; Bennett, N.J.; Boyle, L.H.; Thomas, M.; Trowsdale, J.; Wills, M.R. NKG2D ligand MICA is retained in the cis-Golgi apparatus by human cytomegalovirus protein UL142. J. Virol. 2009, 83, 12345-12354. [CrossRef] [PubMed]

35. Bennett, N.J.; Ashiru, O.; Morgan, F.J.; Pang, Y.; Okecha, G.; Eagle, R.A.; Trowsdale, J.; Sissons, J.G.; Wills, M.R. Intracellular sequestration of the NKG2D ligand ULBP3 by human cytomegalovirus. J. Immunol. 2010, 185, 1093-1102. [CrossRef] [PubMed]

36. Cerboni, C.; Neri, F.; Casartelli, N.; Zingoni, A.; Cosman, D.; Rossi, P.; Santoni, A.; Doria, M. Human immunodeficiency virus 1 Nef protein downmodulates the ligands of the activating receptor NKG2D and inhibits natural killer cell-mediated cytotoxicity. J. Gen. Virol. 2007, 88, 242-250. [CrossRef] [PubMed]

37. Bacon, L.; Eagle, R.A.; Meyer, M.; Easom, N.; Young, N.T.; Trowsdale, J. Two human ULBP/RAET1 molecules with transmembrane regions are ligands for NKG2D. J. Immunol. 2004, 173, 1078-1084. [CrossRef] [PubMed]

38. Cao, W.; Xi, X.; Hao, Z.; Li, W.; Kong, Y.; Cui, L.; Ma, C.; Ba, D.; He, W. RAET1E2, a soluble isoform of the UL16-binding protein RAET1E produced by tumor cells, inhibits NKG2D-mediated NK cytotoxicity. J. Biol. Chem. 2007, 282, 18922-18928. [CrossRef] [PubMed]

39. Waldhauer, I.; Steinle, A. Proteolytic release of soluble UL16-binding protein 2 from tumor cells. Cancer Res. 2006, 66, 2520-2526. [CrossRef] [PubMed]

40. Salih, H.R.; Rammensee, H.G.; Steinle, A. Cutting edge: Down-regulation of MICA on human tumors by proteolytic shedding. J. Immunol. 2002, 169, 4098-4102. [CrossRef] [PubMed]

41. Boutet, P.; Agüera-González, S.; Atkinson, S.; Pennington, C.J.; Edwards, D.R.; Murphy, G.; Reyburn, H.T.; Valés-Gómez, M. Cutting edge: The metalloproteinase ADAM17/TNF- $\alpha$-converting enzyme regulates proteolytic shedding of the MHC class I-related chain B protein. J. Immunol. 2009, 182, 49-53. [CrossRef] [PubMed]

42. Zingoni, A.; Cecere, F.; Vulpis, E.; Fionda, C.; Molfetta, R.; Soriani, A.; Petrucci, M.T.; Ricciardi, M.R.; Fuerst, D.; Amendola, M.G.; et al. Genotoxic Stress Induces Senescence-Associated ADAM10-Dependent Release of NKG2D MIC Ligands in Multiple Myeloma Cells. J. Immunol. 2015, 195, 736-748. [CrossRef] [PubMed]

43. Ashiru, O.; Boutet, P.; Fernández-Messina, L.; Agüera-González, S.; Skepper, J.N.; Valés-Gómez, M.; Reyburn, H.T. Natural killer cell cytotoxicity is suppressed by exposure to the human NKG2D ligand $\mathrm{MICA}^{* 008}$ that is shed by tumor cells in exosomes. Cancer Res. 2010, 70, 481-489. [CrossRef] [PubMed] 
44. Fernández-Messina, L.; Ashiru, O.; Boutet, P.; Agüera-González, S.; Skepper, J.N.; Reyburn, H.T.; Valés-Gómez, M. Differential mechanisms of shedding of the glycosylphosphatidylinositol (GPI)-anchored NKG2D ligands. J. Biol. Chem. 2010, 285, 8543-8551. [CrossRef] [PubMed]

45. Groh, V.; Wu, J.; Yee, C.; Spies, T. Tumour-derived soluble MIC ligands impair expression of NKG2D and T-cell activation. Nature 2002, 419, 734-738. [CrossRef] [PubMed]

46. Doubrovina, E.S.; Doubrovin, M.M.; Vider, E.; Sisson, R.B.; O’Reilly, R.J.; Dupont, B.; Vyas, Y.M. Evasion from NK cell immunity by MHC class I chain-related molecules expressing colon adenocarcinoma. J. Immunol. 2003, 171, 6891-6899. [CrossRef] [PubMed]

47. Ogasawara, K.; Hamerman, J.A.; Hsin, H.; Chikuma, S.; Bour-Jordan, H.; Chen, T.; Pertel, T.; Carnaud, C.; Bluestone, J.A.; Lanier, L.L. Impairment of NK cell function by NKG2D modulation in NOD mice. Immunity 2003, 18, 41-51. [CrossRef]

48. Oppenheim, D.E.; Roberts, S.J.; Clarke, S.L.; Filler, R.; Lewis, J.M.; Tigelaar, R.E.; Girardi, M.; Hayday, A.C. Sustained localized expression of ligand for the activating NKG2D receptor impairs natural cytotoxicity in vivo and reduces tumor immunosurveillance. Nat. Immunol. 2005, 6, 928-937. [CrossRef] [PubMed]

49. Wiemann, K.; Mittrücker, H.W.; Feger, U.; Welte, S.A.; Yokoyama, W.M.; Spies, T.; Rammensee, H.G.; Steinle, A. Systemic NKG2D down-regulation impairs NK and CD8 T cell responses in vivo. J. Immunol. 2005, 175, 720-729. [CrossRef] [PubMed]

50. Clayton, A.; Mitchell, J.P.; Court, J.; Linnane, S.; Mason, M.D.; Tabi, Z. Human tumor-derived exosomes down-modulate NKG2D expression. J. Immunol. 2008, 180, 7249-7258. [CrossRef] [PubMed]

51. Molfetta, R.; Quatrini, L.; Capuano, C.; Gasparrini, F.; Zitti, B.; Zingoni, A.; Galandrini, R.; Santoni, A.; Paolini, R. c-Cbl regulates MICA- but not ULBP2-induced NKG2D down-modulation in human NK cells. Eur. J. Immunol. 2014, 44, 2761-2770. [CrossRef] [PubMed]

52. Molfetta, R.; Quatrini, L.; Zitti, B.; Capuano, C.; Galandrini, R.; Santoni, A.; Paolini, R. Regulation of NKG2D Expression and Signaling by Endocytosis. Trends Immunol. 2016, 37, 790-802. [CrossRef] [PubMed]

53. Von Lilienfeld-Toal, M.; Frank, S.; Leyendecker, C.; Feyler, S.; Jarmin, S.; Morgan, R.; Glasmacher, A.; Märten, A.; Schmidt-Wolf, I.G.; Brossart, P.; et al. Reduced immune effector cell NKG2D expression and increased levels of soluble NKG2D ligands in multiple myeloma may not be causally linked. Cancer Immunol. Immunother. 2010, 59, 829-839. [CrossRef] [PubMed]

54. Groh, V.; Bruhl, A.; El-Gabalawy, H.; Nelson, J.L.; Spies, T. Stimulation of T cell autoreactivity by anomalous expression of NKG2D and its MIC ligands in rheumatoid arthritis. Proc. Natl. Acad. Sci. USA 2003, 100, 9452-9457. [CrossRef] [PubMed]

55. Hüe, S.; Mention, J.J.; Monteiro, R.C.; Zhang, S.; Cellier, C.; Schmitz, J.; Verkarre, V.; Fodil, N.; Bahram, S.; Cerf-Bensussan, N.; et al. A direct role for NKG2D/MICA interaction in villous atrophy during celiac disease. Immunity 2004, 21, 367-377. [CrossRef] [PubMed]

56. Meresse, B.; Chen, Z.; Ciszewski, C.; Tretiakova, M.; Bhagat, G.; Krausz, T.N.; Raulet, D.H.; Lanier, L.L.; Groh, V.; Spies, T.; et al. Coordinated induction by IL15 of a TCR-independent NKG2D signaling pathway converts CTL into lymphokine-activated killer cells in celiac disease. Immunity 2004, 21, 357-366. [CrossRef] [PubMed]

57. Song, H.; Kim, J.; Cosman, D.; Choi, I. Soluble ULBP suppresses natural killer cell activity via down-regulating NKG2D expression. Cell Immunol. 2006, 239, 22-30. [CrossRef] [PubMed]

58. Cerboni, C.; Ardolino, M.; Santoni, A.; Zingoni, A. Detuning CD8 ${ }^{+}$T lymphocytes by down-regulation of the activating receptor NKG2D: Role of NKG2D ligands released by activated T cells. Blood 2009, 113, 2955-2964. [CrossRef] [PubMed]

59. Hedlund, M.; Stenqvist, A.C.; Nagaeva, O.; Kjellberg, L.; Wulff, M.; Baranov, V.; Mincheva-Nilsson, L. Human placenta expresses and secretes NKG2D ligands via exosomes that down-modulate the cognate receptor expression: Evidence for immunosuppressive function. J. Immunol. 2009, 183, 340-351. [CrossRef] [PubMed]

60. Champsaur, M.; Beilke, J.N.; Ogasawara, K.; Koszinowski, U.H.; Jonjic, S.; Lanier, L.L. Intact NKG2D-independent function of NK cells chronically stimulated with the NKG2D ligand Rae-1. J. Immunol. 2010, 185, 157-165. [CrossRef] [PubMed]

61. Coudert, J.D.; Zimmer, J.; Tomasello, E.; Cebecauer, M.; Colonna, M.; Vivier, E.; Held, W. Altered NKG2D function in NK cells induced by chronic exposure to NKG2D ligand-expressing tumor cells. Blood 2005, 106, 1711-1717. [CrossRef] [PubMed] 
62. Deng, W.; Gowen, B.G.; Zhang, L.; Wang, L.; Lau, S.; Iannello, A.; Xu, J.; Rovis, T.L.; Xiong, N.; Raulet, D.H. Antitumor immunity. A shed NKG2D ligand that promotes natural killer cell activation and tumor rejection. Science 2015, 348, 136-139. [CrossRef] [PubMed]

63. Hanaoka, N.; Jabri, B.; Dai, Z.; Ciszewski, C.; Stevens, A.M.; Yee, C.; Nakakuma, H.; Spies, T.; Groh, V. NKG2D initiates caspase-mediated $\mathrm{CD} 3 \zeta$ degradation and lymphocyte receptor impairments associated with human cancer and autoimmune disease. J. Immunol. 2010, 185, 5732-5742. [CrossRef] [PubMed]

64. Coudert, J.D.; Scarpellino, L.; Gros, F.; Vivier, E.; Held, W. Sustained NKG2D engagement induces cross-tolerance of multiple distinct NK cell activation pathways. Blood 2008, 111, 3571-3578. [CrossRef] [PubMed]

65. Lee, J.C.; Lee, K.M.; Kim, D.W.; Heo, S.D. Elevated TGF- $\beta 1$ Secretion and Down-Modulation of NKG2D Underlies Impaired NK Cytotoxicity in Cancer Patients. J. Immunol. 2004, 172, 7335-7340. [CrossRef] [PubMed]

66. Park, Y.P.; Choi, S.C.; Kiesler, P.; Gil-Krzewska, A.; Borrego, F.; Weck, J.; Krzewski, K.; Coligan, J.E. Complex regulation of human NKG2D-DAP10 cell surface expression: Opposing roles of the $\gamma_{c}$ cytokines and TGF- $\beta 1$. Blood 2011, 118, 3019-3027. [CrossRef] [PubMed]

67. Sun, C.; Fu, B.; Gao, Y.; Liao, X.; Sun, R.; Tian, Z.; Wei, H. TGF- $\beta 1$ down-regulation of NKG2D/DAP10 and 2B4/SAP expression on human NK cells contributes to HBV persistence. PLoS Pathog. 2012, 8, e1002594. [CrossRef] [PubMed]

68. Roda-Navarro, P.; Reyburn, H.T. The traffic of the NKG2D/Dap10 receptor complex during natural killer (NK) cell activation. J. Biol. Chem. 2009, 284, 16463-16472. [CrossRef] [PubMed]

69. Quatrini, L.; Molfetta, R.; Zitti, B.; Peruzzi, G.; Fionda, C.; Capuano, C.; Galandrini, R.; Cippitelli, M.; Santoni, A.; Paolini, R. Ubiquitin-dependent endocytosis of NKG2D-DAP10 receptor complexes activates signaling and functions in human NK cells. Sci. Signal. 2015, 8, ra108. [CrossRef] [PubMed]

70. Horng, T.; Bezbradica, J.S.; Medzhitov, R. NKG2D signaling is coupled to the interleukin 15 receptor signaling pathway. Nat. Immunol. 2007, 8, 1345-1352. [CrossRef] [PubMed]

71. Galandrini, R.; Capuano, C.; Santoni, A. Activation of Lymphocyte Cytolytic Machinery: Where are we? Front. Immunol. 2013, 4, 390. [CrossRef] [PubMed]

72. Irannejad, R.; Tsvetanova, N.G.; Lobingier, B.T.; von Zastrow, M. Effects of endocytosis on receptor-mediated signaling. Curr. Opin. Cell Biol. 2015, 35, 137-143. [CrossRef] [PubMed]

73. Bergeron, J.J.; di Guglielmo, G.M.; Dahan, S.; Dominguez, M.; Posner, B.I. Spatial and Temporal Regulation of Receptor Tyrosine Kinase Activation and Intracellular Signal Transduction. Annu. Rev. Biochem. 2016, 85, 573-597. [CrossRef] [PubMed]

74. Brubaker, S.W.; Bonham, K.S.; Zanoni, I.; Kagan, J.C. Innate immune pattern recognition: A cell biological perspective. Annu. Rev. Immunol. 2015, 33, 257-290. [CrossRef] [PubMed]

75. Kagan, J.C.; Su, T.; Horng, T.; Chow, A.; Akira, S.; Medzhitov, R. TRAM couples endocytosis of Toll-like receptor 4 to the induction of interferon- $\beta$. Nat. Immunol. 2008, 9, 361-368. [CrossRef] [PubMed]

76. Chaturvedi, A.; Martz, R.; Dorward, D.; Waisberg, M.; Pierce, S.K. Endocytosed BCRs sequentially regulate MAPK and Akt signaling pathways from intracellular compartments. Nat. Immunol. 2011, 12, 1119-1126. [CrossRef] [PubMed]

77. Willinger, T.; Staron, M.; Ferguson, S.M.; de Camilli, P.; Flavell, R.A. Dynamin 2-dependent endocytosis sustains T-cell receptor signaling and drives metabolic reprogramming in T lymphocytes. Proc. Natl. Acad. Sci. USA 2015, 112, 4423-4428. [CrossRef] [PubMed]

78. Rajagopalan, S.; Bryceson, Y.T.; Kuppusamy, S.P.; Geraghty, D.E.; van der Meer, A.; Joosten, I.; Long, E.O. Activation of NK cells by an endocytosed receptor for soluble HLA-G. PLoS Biol. 2006, 4, e9. [CrossRef] [PubMed]

79. Miah, S.M.; Purdy, A.K.; Rodin, N.B.; MacFarlane IV, A.W.; Oshinsky, J.; Alvarez-Arias, D.A.; Campbell, K.S. Ubiquitylation of an internalized killer cell Ig-like receptor by Triad3A disrupts sustained NF- $\mathrm{B}$ signaling. J. Immunol. 2011, 186, 2959-2969. [CrossRef] [PubMed]

80. Fauriat, C.; Just-Landi, S.; Mallet, F.; Arnoulet, C.; Sainty, D.; Olive, D.; Costello, R.T. Deficient expression of NCR in NK cells from acute myeloid leukemia: Evolution during leukemia treatment and impact of leukemia cells in NCRdull phenotype induction. Blood 2007, 109, 323-330. 
81. El-Sherbiny, Y.M.; Meade, J.L.; Holmes, T.D.; McGonagle, D.; Mackie, S.L.; Morgan, A.W.; Cook, G.; Feyler, S.; Richards, S.J.; Davies, F.E.; et al. The requirement for DNAM-1, NKG2D, and NKp46 in the natural killer cell-mediated killing of myeloma cells. Cancer Res. 2007, 67, 8444-8449. [CrossRef] [PubMed]

82. Carlsten, M.; Norell, H.; Bryceson, Y.T.; Poschke, I.; Schedvins, K.; Ljunggren, H.G.; Kiessling, R.; Malmberg, K.J. Primary human tumor cells expressing CD155 impair tumor targeting by down-regulating DNAM-1 on NK cells. J. Immunol. 2009, 183, 4921-4930. [CrossRef] [PubMed]

83. Sanchez-Correa, B.; Gayoso, I.; Bergua, J.M.; Casado, J.G.; Morgado, S.; Solana, R.; Tarazona, R. Decreased expression of DNAM-1 on NK cells from acute myeloid leukemia patients. Immunol. Cell Biol. 2012, 90, 109-115. [CrossRef] [PubMed]

84. Zhou, Q.; Gil-Krzewska, A.; Peruzzi, G.; Borrego, F. Matrix metalloproteinases inhibition promotes the polyfunctionality of human natural killer cells in therapeutic antibody-based anti-tumour immunotherapy. Clin. Exp. Immunol. 2013, 173, 131-139. [CrossRef] [PubMed]

85. Pesce, S.; Tabellini, G.; Cantoni, C.; Patrizi, O.; Coltrini, D.; Rampinelli, F.; Matta, J.; Vivier, E.; Moretta, A.; Parolini, S.; et al. B7-H6-mediated downregulation of NKp30 in NK cells contributes to ovarian carcinoma immune escape. Oncoimmunology 2015, 4, e1001224. [CrossRef] [PubMed]

86. Semeraro, M.; Rusakiewicz, S.; Minard-Colin, V.; Delahaye, N.F.; Enot, D.; Vély, F.; Marabelle, A.; Papoular, B.; Piperoglou, C.; Ponzoni, M.; et al. Clinical impact of the NKp30/B7-H6 axis in high-risk neuroblastoma patients. Sci. Transl. Med. 2015, 7, 283ra55. [CrossRef] [PubMed]

87. Capuano, C.; Romanelli, M.; Pighi, C.; Cimino, G.; Rago, A.; Molfetta, R.; Paolini, R.; Santoni, A.; Galandrini, R. Anti-CD20 Therapy Acts via Fc $\gamma$ RIIIA to Diminish Responsiveness of Human Natural Killer Cells. Cancer Res. 2015, 75, 4097-4108. [CrossRef] [PubMed]

88. Capuano, C.; Pighi, C.; Molfetta, R.; Paolini, R.; Battella, S.; Palmieri, G.; Giannini, G.; Belardinilli, F.; Santoni, A.; Galandrini, R. Obinutuzumab-mediated high-affinity ligation of Fc $\gamma$ RIIIA/CD16 primes NK cells for IFN $\gamma$ production. Oncoimmunology 2017, 6, e1290037. [CrossRef] [PubMed]

89. Kruse, P.H.; Matta, J.; Ugolini, S.; Vivier, E. Natural cytotoxicity receptors and their ligands. Immunol. Cell Biol. 2014, 92, 221-229. [CrossRef] [PubMed]

90. Moretta, A.; Bottino, C.; Vitale, M.; Pende, D.; Cantoni, C.; Mingari, M.C.; Biassoni, R.; Moretta, L. Activating receptors and coreceptors involved in human natural killer cell-mediated cytolysis. Annu. Rev. Immunol. 2001, 19, 197-223. [CrossRef] [PubMed]

91. Brandt, C.S.; Baratin, M.; Yi, E.C.; Kennedy, J.; Gao, Z.; Fox, B.; Haldeman, B.; Ostrander, C.D.; Kaifu, T.; Chabannon, C.; et al. The B7 family member B7-H6 is a tumor cell ligand for the activating natural killer cell receptor NKp30 in humans. J. Exp. Med. 2009, 206, 1495-1503. [CrossRef] [PubMed]

92. Martinet, L.; Smyth, M.J. Balancing natural killer cell activation through paired receptors. Nat. Rev. Immunol. 2015, 15, 243-254. [CrossRef] [PubMed]

93. Nimmerjahn, F.; Ravetch, J.V. Fc $\gamma$ receptors as regulators of immune responses. Nat. Rev. Immunol. 2008, 8, 34-44. [CrossRef] [PubMed]

94. O'Shea, J.J.; Weissman, A.M.; Kennedy, I.C.; Ortaldo, J.R. Engagement of the natural killer cell IgG Fc receptor results in tyrosine phosphorylation of the zeta chain. Proc. Natl. Acad. Sci. USA 1991, 88, 350-354. [CrossRef] [PubMed]

95. Galandrini, R.; Palmieri, G.; Paolini, R.; Piccoli, M.; Frati, L.; Santoni, A. Selective binding of shc-SH2 domain to tyrosine-phosphorylated $\zeta$ but not $\gamma$-chain upon CD16 ligation on human NK cells. J. Immunol. 1997, 159, 3767-3773. [PubMed]

96. Natsume, A.; Niwa, R.; Satoh, M. Improving effector functions of antibodies for cancer treatment: Enhancing ADCC and CDC. Drug Des. Dev. Ther. 2009, 3, 7-16. [CrossRef]

97. García-Foncillas, J.; Díaz-Rubio, E. Progress in metastatic colorectal cancer: Growing role of cetuximab to optimize clinical outcome. Clin. Transl. Oncol. 2010, 12, 533-542. [CrossRef] [PubMed]

98. Garnock-Jones, K.P.; Keating, G.M.L.; Scott, J. Trastuzumab: A review of its use as adjuvant treatment in human epidermal growth factor receptor 2 (HER2)-positive early breast cancer. Drugs 2010, 70, 215-239. [CrossRef] [PubMed]

99. Borrego, F.; Lopez-Beltran, A.; Pena, J.; Solana, R. Downregulation of Fc $\gamma$ receptor IIIA $\alpha$ (CD16-II) on natural killer cells induced by anti-CD16 $\mathrm{mAb}$ is independent of protein tyrosine kinases and protein kinase $\mathrm{C}$. Cell Immunol. 1994, 158, 208-217. [CrossRef] [PubMed] 
100. Grzywacz, B.; Kataria, N.; Verneris, M.R. CD56 ${ }^{\operatorname{dim}} \mathrm{CD} 16^{+}$NK cells downregulate CD16 following target cell induced activation of matrix metalloproteinases. Leukemia 2007, 21, 356-359. [CrossRef] [PubMed]

101. Romee, R.; Foley, B.; Lenvik, T.; Wang, Y.; Zhang, B.; Ankarlo, D.; Luo, X.; Cooley, S.; Verneris, M.; Walcheck, B.; et al. NK cell CD16 surface expression and function is regulated by a disintegrin and metalloprotease-17 (ADAM17). Blood 2013, 121, 3599-3608. [CrossRef] [PubMed]

102. Peruzzi, G.; Femnou, L.; Gil-Krzewska, A.; Borrego, F.; Weck, J.; Krzewski, K.; Coligan, J.E. Membrane-type 6 matrix metalloproteinase regulates the activation-induced downmodulation of CD16 in human primary NK cells. J. Immunol. 2013, 191, 1883-1889. [CrossRef] [PubMed]

103. Mota, G.; Moldovan, I.; Calugaru, A.; Hirt, M.; Kozma, E.; Galatiuc, C.; Brasoveanu, L.; Boltz-Nitulescu, G. Interaction of human immunoglobulin $\mathrm{G}$ with CD16 on natural killer cells: Ligand clearance, FcgammaRIIIA turnover and effects of metalloproteinases on Fc $\gamma$ RIIIA-mediated binding, signal transduction and killing. Scand. J. Immunol. 2004, 59, 278-284. [CrossRef] [PubMed]

104. Cecchetti, S.; Spadaro, F.; Lugini, L.; Podo, F.; Ramoni, C. Functional role of phosphatidylcholine-specific phospholipase C in regulating CD16 membrane expression in natural killer cells. Eur. J. Immunol. 2007, 37, 2912-2922. [CrossRef] [PubMed]

105. Paolini, R.; Serra, A.; Molfetta, R.; Piccoli, M.; Frati, L.; Santoni, A. Tyrosine kinase-dependent ubiquitination of CD16 zeta subunit in human NK cells following receptor engagement. Eur. J. Immunol. 1999, 29, 3179-3187. [CrossRef]

106. Paolini, R.; Molfetta, R.; Piccoli, M.; Frati, L.; Santoni, A. Ubiquitination and degradation of Syk and ZAP-70 protein tyrosine kinases in human NK cells upon CD16 engagement. Proc. Natl. Acad. Sci. USA 2001, 98, 9611-9616. [CrossRef] [PubMed]

(C) 2017 by the authors. Licensee MDPI, Basel, Switzerland. This article is an open access article distributed under the terms and conditions of the Creative Commons Attribution (CC BY) license (http:/ / creativecommons.org/licenses/by/4.0/). 